\title{
REFERENCES
}

Lur'e, L. and Maliarov, L. (2012) Leningradskii front. St. Petersburg, BKhV-Peterburg. 272 p.

Blokada Leningrada $v$ dokumentakb rassekrechennykb arkbivov (2004) / ed. by N. L. Volkovskogo. Moscow, AST; St. Petersburg, Poligon. 766 [1] p.

Burov, A. V. (1979) Blokada den' za dnem. Lenongrad, Lenizdat. 478 p.

Iampol'skii, V. (2008) "...Unichtozbit' Rossiiu vesnoi 1941 g." (A. Gitler. 31 iiulia 1941 goda): Dokumenty spetssluzhb SSSR $i$ Germanii 1937-1945 gg. Moscow, Kuchkovo pole. 656 p.

Submission date: 10.02 .2020 .

Ильинский Игорь Михайлович - доктор философских наук, профессор, ректор Московского гуманитарного университета. Адрес: 111395, Россия, г. Москва, ул. Юности, д. 5. Тел.: +7 (499) 374-78-78. Эл. aspec: iilinskiy@mosgu.ru

Ilinskiy Igor Mikhailovich, Doctor of Philosophy, Professor, Rector, Moscow University for the $\mathrm{Hu}-$ manities. Postal address: 5, Yunosti St., Moscow, Russian Federation, 111395. Tel.: +7 (499) 374-78-78. E-mail: iilinskiy@mosgu.ru

DOI: $10.17805 /$ zpu.2020.2.2

\section{Как предотвратили депортацию финно-угорских народов в 1944 г.}

\author{
Ю. А. ВАСИЛЬЕВ \\ МОСКОВСКИЙ ГУМАНИТАРНЫЙ УНИВЕРСИТЕТ
}

В статье освещается уникальный и практически неизвестный исторический факт о предотвращении депортации финно-угорского населения СССР в 1944 г. на территории Ленинградской области и Карело-Финской ССР, освобожденной войсками Карельского фронта от оккупации. Упоминание о нем впервые появилось в средствах массовой информации Финляндии в конце 1980-х - начале 1990-х гг. Однако научной историографии по данной проблеме до сих пор нет.

Как свидетельствуют документы Российского государственного архива социально-политической истории (РГАСПИ), обнаруженные в результате целенаправленного исследовательского поиска автора, в ходе наступления Карельского фронта в июне - августе 1944 г. возникла реальная угроза возможного выселения ингерманландцев, карел, финнов, вепсов и других коренных северных народов, оказавшихся в годы Великой Отечественной войны на территории, оккупированной финляндскими и немецкими войсками.

Раскрывается содержание докладной записки военного корреспондента газеты «Правда» М. М. Шура в редколлегию главного партийного органа СССР, в которой в жесткой форме констатировалось наличие угрозы насильственных мероприятий в отношении финноугорского населения. По определению военкора, обострение национального вопроса получило наименование «карельский вопрос». Освещаются коллизии, связанные с дальнейшим его обсуждением в ЦК ВКП(б), участием высшего партийного руководства страны секретарей ЦК партии Г. М. Маленкова, А. А. Жданова, А. С. Щербакова, главного редактора газеты «Правда» П. Н. Поспелова.

По утверждению автора, предотвращение депортации на Севере в 1944 г. было осуществлено по указанию «высшей инстанции» - Верховного главнокомандующего И. В. Сталина. Принятие данного решения обосновано геополитической ситуацией, государствен- 
ными интересами СССР и Финляндии, результатом чего стало заключение перемирия в Москве 19 сентября 1944 г.

Ключевые слова: Великая Отечественная война; Карельский фронт; карельский вопрос; депортация; секретариат ЦК ВКП(б); И. В. Сталин; М. М. Шур; Г. Н. Куприянов; Т. Ф. ШтыкОВ

\section{ВВЕАЕНИЕ}

$\Pi$ редметом изучения автора статьи явился малоизвестный исторический факт: летом 1944 г., в период успешного наступления Карельского фронта (Свирской, Сортавальской, Петрозаводской операций), финно-угорское население (ингерманландцы, карелы, финны, вепсы) оказалось встревожено слухами о готовящемся насильственном выселении местных жителей в отдаленные регионы страны. Тема о несостоявшейся депортации финно-угорского населения в течение многих десятилетий не только не изучалась исследователями, но даже не упоминалась. Однако в конце 1980-х — начале 1990-х гг. в средствах массовой информации в Финляндии появились утверждения о подготовке депортации финно-угорского населения на Севере в 1944 г. В книге современного финляндского автора А. Уйтто повторяются заявления о предложении руководителей Карельского фронта в 1944 г. выслать в отдаленные районы страны представителей коренных народов в связи с якобы «массовым предательством» и пособничеством оккупантам (см.: Уйтто, 2017: 320). Однако автор не привел документальных доказательств своим утверждениям. Публикации российских историков позволяют констатировать отсутствие оснований для репрессивных мер в отношении населения, оказавшегося в оккупации (см.: Веригин, 2009: 432).

Трехлетний поиск автора данной публикации в фондах Российского государственного архива социально-политической истории (РГАСПИ) дал возможность ввести в научный оборот новые архивные документы (в частности, материалы Управления кадров ЦК ВКП(б), техсекретариата ЦК), что позволяет представить достоверную репрезентацию исторических событий. История несостоявшейся депортации финноугорских народов является актуальной исследовательской проблемой в рамках современной парадигмы новой политической истории, включающей рассмотрение национальных и духовных особенностей различных социальных групп, в том числе сельского, составлявшего в 1940-е годы основную часть финно-угорского населения (см.: Васильев, 1992: 79-85).

\section{«КАРЕАЬСКИЙ ВОПРОС»}

В проблематике данной темы есть немало важных сюжетов, которые необходимы для ее интерпретации, осмысления и понимания.

Одним из них является авторство постановки национального вопроса. «Карельский вопрос» как определение угрозы насильственного выселения финно-угорских народов из родных мест связан с письмом военного корреспондента газеты «Правда» М. М. Шура, датированным 31 июля 1944 г., в редколлегию главного партийного издания в СССР с описанием и оценкой ситуации в освобожденных районах. Автор шестистраничного письма констатировал, что наступательные бои, начавшиеся на Свири 21 июня 1944 г., имели несомненный успех: к середине июля советские части в отдельных местах достигли государственной границы. Наступление в сложных климатических и природных северных условиях потребовало от воинов фронта «большой выносливости» (РГАСПИ. Ф. 17. Оп. 121. А. 332. А. 85). 
Аалее военкор Михаил Шур дал характеристику «поведению противника». Он отметил, что оккупанты нанесли «огромный материальный ущерб»: они «...хищнически пользовали лесные участки, вывезли в Финляндию огромное количество леса и древесины. На лесоразработках применялся принудительный труд населения, в частности русских людей, сидевших в концлагерях» (там же: л. 87). По его свидетельству, местные жители подвергались издевательствам, грабежам, насилию. В результате финляндские оккупанты не получили поддержки от родственного населения, на которую изначально рассчитывали. Военкор «Правды» особо подчеркивал, что «вся молодежь сочувственно относилась» к партизанам и подпольщикам (там же: л. 88).

Аалее офицер-правдист Михаил Шур поставил проблему, которую определил как «карельский вопрос». Он сообщил руководству газеты, что «в некоторых воинских частях и штабах》 распространяется «вздорное и совершенно необоснованное мнение» о негостеприимном отношении карел к Красной армии, о том, что представители местных народов якобы «сжились с финнами» и враждебны советской власти. Подобных «распространителей» слухов Шур называл «недальновидными людьми, живущими этими настроениями» (там же). Отрицалось какое-либо массовое пособничество местного населения финляндским властям в период оккупации. По оценке Шура, «в отличие... от крымских татар (позднее подобное сравнение приписали И. В. Сталину. - Ю. В.), карелы не дезертировали из Красной Армии, а сражались в ее рядах...» (там же). Констатировалось, что местное карело-финское население не ушло с отступающими финскими войсками, несмотря на активную агитацию и подачки, наоборот, оно выдвинуло массу народных героев. Подавляющее большинство честно и самоотверженно работали на пользу фронту. В деревнях происходил стихийный массовый сбор продовольствия в фонд помощи Красной армии. Народ трудился с утра до вечера на восстановлении дорог и строительстве мостов (РГАСПИ. Ф. 17. Оп. 121. А. 332. А. 88-89). Однако, как свидетельствовал военкор «Правды», со стороны военных отмечались факты мародерства и хулиганства в отношении местного населения (кража коров, порча посевов, грабеж имущества и т. п.). В естественной негативной реакции жителей на подобные «хамские выходки, провоцирующие вражду к Красной Армии», «легкомысленные политработники некоторых частей», по свидетельству М. М. Шура, видели враждебность местного населения (там же: л. 89).

Военкор «Правды» характеризовал северных жителей как «хладнокровный, молчаливый народ», который присматривался в первые дни к освободителям, люди побаивались армии: а не накажут ли за то, что оказались в оккупации? (там же). Основания для этого имели место, в том числе факты произвола со стороны отдельных военных работников. Военный корреспондент приводил пример «вопиющего безобразия» со стороны майора Павла Шубина, сотрудника фронтовой газеты Карельского фронта «В бой за Родину», который был замечен в пьяных дебошах. Он приехал в одну из олонецких деревень, собрал жителей и объявил местному населению освобожденных районов о скором выселении их в Сибирь, что он лично явится через две недели и займется выселением. Шубин допустил насилие в отношении карельских девушек, одну из них ударил рукояткой пистолета по голове, ее с трудом отбили оказавшиеся поблизости офицеры. Военный корреспондент «Правды» свидетельствовал: «Я читал в прокуратуре показания свидетелей - бойцов и офицеров, местных жителей и самой потерпевшей, а также заключение военного врача, освидетельствовавшего потерпевшую» (там же). 
Этот эпизод вызвал возмущение у жителей небольшого древнего карельского города Олонца. Военкор в этой связи констатировал, что «нужно было бы по крайней мере публично судить негодяя», но «Шубин до сих пор ходит на свободе» (там же). Причина виделась в том, что работники Политуправления Карельского фронта затеяли собственное расследование, чтобы «замазать преступление» с целью якобы защиты репутации военных, выдумывая «вздорные и глупые придирки к карелам» (там же: л. 89-90).

Собственную позицию в «карельском вопросе» М. М. Шур выразил предельно конкретно. Он написал в редколлегию «Правды»: «Иично я могу со всей ответственностью заявить, что карелы вели себя при противнике и встретили затем Красную Армию ничуть не менее достойно, чем население Кубани, Аона, Украины, где мне пришлось побывать во время наступления» (там же: л. 90).

Боевой опыт советского офицера позволял ему делать подобные сравнения: всю войну он прошел в качестве военкора газеты «Правда» на различных фронтах. М. М. Шур требовал прекратить всякие досужие разговоры о якобы враждебности финно-угорских народов, прекратить оскорбительные выходки по отношению к ним, а распространение слухов о выселении рассматривать как «проявление шовинизма и черносотенщины» (там же).

Как свидетельствует содержание письма военкора в редколлегию «Правды», существовало принципиальное разногласие его автора с партийным руководителем Карело-Финской ССР Г. Н. Куприяновым в оценке подпольной деятельности на оккупированной территории республики. В частности, по данным капитана М. Шура, в карельском Шелтозере сформировалась массовая подпольная организация. Однако, как утверждал военкор, это была не партийная, а советская подпольная организация, состоящая из беспартийных людей и молодежи, согнанных оккупантами на строительство оборонительных укреплений в районе Свири. Термин «советская» был подчеркнут в докладной записке (там же: л. 88). Таким образом, офицер- «правдист» в своей оценке, по сути, говорил об ограниченном влиянии партийного руководства: советская подпольная организация олицетворяла народную инициативу в организации подпольной борьбы с оккупантами. Конечно, подобное высказывание являлось серьезным ударом по амбициям Г. Н. Куприянова, который позиционировал себя в качестве руководителя и организатора подпольной деятельности в республике. Вероятно, в трактовке военкора, поставленной перед руководством газеты «Правда», партийный руководитель увидел угрозу собственному положению в политической элите. Он понимал, что данное мнение может быть поддержано в центральном партийном органе в Москве.

Главный редактор «Правды» П. Н. Поспелов получил письмо в Москве 5 августа 1944 г. О реакции редколлегии на письмо военкора газеты можно было бы узнать на основании фонда архивных документов редакции «Правды». Однако приходится констатировать удивительное явление: до сих пор все 30 описей советского периода главного партийного печатного органа страны в РГАСПИ (бывшем Центральном партийном архиве ИМ $А$ при ЦК КПСС) не обработаны, соответственно, не доступны для исследователей.

Можно лишь сделать предположение о важности оценки проблемы, поставленной М. М. Шуром, в редколлегии «Правды». Об этом свидетельствует факт, что 13 августа П. Н. Поспелов направил докладную записку М. М. Шура члену ГКО, секретарю ЦК ВКП(б) А. А. Жданову. На записке сохранилась резолюция Жданова от 16 ав- 
густа, адресованная секретарям ЦК партии Г. М. Маленкову и А. С. Щербакову: «Просьба ознакомиться. Не следует ли обменяться мнениями на Секретариате?» (там же: л. 92).

Авумя днями позднее, 15 августа, аналогичное послание П. Н. Поспелов отправил также секретарю ЦК партии А. С. Щербакову - руководителю Главного политического управления РККА и председателю Совинформбюро. После ознакомления с содержанием письма военкора «Правды» Щербаков оставил запись крупным почерком карандашом синего цвета, адресованную Маленкову: «1) Аело поэта Шубина я приказал срочно расследовать. 2) Надо бы инструктировать тт. [товарищей], которые поедут в Карелию, серьезно изучить и ту сторону вопроса, о которой пишет т. Шур. 17.08.1944» (там же: $л .84)$.

Резолюция Маленкова с персональным поручением ответорганизатору Управления кадров ЦК партии В. И. Репину разобраться в этом деле начертана красным карандашом, этим же красным цветом выделены два сюжета в письме Шура: эпизод, связанный с преступным поведением майора Шубина, и заключение, в котором высказана позиция военкора по поводу «карельского вопроса», особенно формулировка о «проявлении шовинизма и черносотенщины».

Факты, о которых сообщал военкор капитан Шур, подтвердились. П. Шубин, допустивший насилие в отношении карельской девушки-учительницы, был наказан военным трибуналом. Защитил его член Военного совета фронта Т. Ф. Штыков, которому удалось добиться существенного смягчения приговора. Именно генерал Штыков привел за собой автора знаменитой «Волховской застольной» поэта Павла Шубина с Волховского фронта на Карельский.

К разбору дела сотрудники Управления кадров ЦК ВКП(б) подключили партийного руководителя Карело-Финской ССР Г. Н. Куприянова. В послевоенные годы бывший партийный руководитель республики приписал главную роль в решении данного вопроса собственной персоне. В Национальном архиве Республики Карелия (НА РК) в личном фонде Куприянова хранится его рукопись под названием «Национальный вопрос» (НА РК. Р-3435. Оп. 2. А. 244). Он утверждал, что обсуждение вопроса состоялось на заседании секретариата ЦК ВКП(б) 30 августа 1944 г. Насколько версия Г. Н. Куприянова соответствует реалиям?

Несомненно, Куприянов знал о содержании письма военкора Шура в «Правду». Не в этом ли заключалась мотивация его решительных действий, связанных со срочной подготовкой доклада в ЦК партии, который оказался в приложении к двум письмам, адресованным секретарям ЦК ВКП(б) А. А. Жданову и Г. М. Маленкову?

В техсекретариате Оргбюро ЦК партии удалось обнаружить эти два документа. Первый - двухстраничная записка Куприянова, адресованная секретарю ЦК ВКП(б) Жданову. В ней сообщалось: «Вопрос о том, как карелы, финны и вепсы вели и ведут себя в Великой Отечественной войне - является вопросом большой политической важности» (РГАСПИ. Ф. 17. Оп. 121. А. 292. А. 1). В этой связи отмечалось следующее: «У некоторых, главным образом, военных работников, появились мнения, что "карелы сплошь все предатели", что они помогали финнам. Кое-где появились слухи, потом оказавшиеся ложью, что в Олонецком районе местные жители якобы зарезали 35 человек наших раненых, один майор в Олонце в пьяном виде публично заявил: "Скоро всех карел выселят в Сибирь”. Подполковник из 69 бригады (фамилию не удалось установить) заявил учительнице-карелке в деревне Коткозеро: “Скоро вас, карел, всех вышлют”. Это как раз то, чем финны запугивали карел при отступлении, приглашая их 
в Финляндию» (там же: л. 1-2). Завершалось письмо словами: «...карельский народ с честью дрался и дерется с врагом... он остался верен своей Советской Родине. Единицы мерзавцев, изменивших Родине, не могут бросить тень на весь карельский народ» (там же: л. 2).

К докладной записке прилагался объемный доклад (69 машинописных страниц) «Об участии карело-финского народа в Великой Отечественной войне», датированный 31 июля 1944 г. Подобные доклады, как свидетельствуют архивные материалы, составлялись партийными органами во всех освобожденных территориях страны. Письмо Куприянова Жданову заканчивалось обращением: «Прошу ознакомиться и дать мне Ваши указания» (там же: л. 1-2; курсив наш. - Ю. В.).

Второй архивный документ - трехстраничная докладная записка Куприянова секретарю ЦК ВКП(б) Маленкову от 3 августа 1944 г. В ней сообщалось: «...у отдельных военных работников, в особенности в первый период нашего наступления, сложилось неправильное представление о карелах. Кое-кто начал охаивать всех карел. Появились слухи, явно провокационные, о том, что где-то “карелы отравили молоком 10 чел[овек] наших бойцов”, что “одна парикмахерша - карелка зарезала нашего лейтенанта”. Эти версии стали раздуваться и в письмах наших бойцов и офицеров к родным и знакомым и описываются как правдоподобные, факты эти обобщаются, и по этим фактам (явно вымышленным) бросается обвинение всему карельскому народу. И это мнение о карелах может распространиться по всей стране. Кое-кто из этих фактов делает орг[анизационные] выводы. Так, майор Шубин в г. Олонце открыто заявил при большой массе народа: “Скоро вас, карел, всех выселят в Сибирь”. Я рассматриваю такие заявления как явно провокационные, играющие на руку врагу, ибо финны, когда отступали и, приглашая карел переселяться в Финляндию, как раз упорно и широко распространяли версию и запугивали карел тем, что “вот придут большевики, они всех вас выселят в лагеря в Сибирь”» (РГАСПИ. Ф. 17. Оп. 122. А. 67. А. 1-2). Заканчивалось письмо констатацией: «...карельский народ остался верен своей Советской Родине, вел и ведет себя так, как этого требуют интересы нашей борьбы с врагом... он честно выдержал и выдерживает все испытания войны» (там же: л. 2). К записке прилагался тот же обширный доклад «Об участии карело-финского народа в Великой Отечественной войне». Куприянов просил Маленкова высказать мнение ЦК партии и «дать соответствуюшие указания» (там же: л. 1-3; курсив наш. - Ю. В.). Таким образом, партийный руководитель союзной республики просил указаний от высшего руководства.

Аокументальное расследование о рассмотрении «карельского вопроса» в ЦК ВКП(б) показало следующее. Как удалось выяснить, подлинник протокола № 169 заседаний Секретариата ЦК партии, подписанный Г. М. Маленковым, включает материалы с хронологическими рамками от 28 августа по 12 сентября 1944 г. В документах заседания от 30 августа вопроса по Карело-Финской республике не было вообще. В архивном фонде техсекретариата ЦК ВКП(б) сохранилась короткая докладная записка на листке бумаги размером в полстраницы, подписанная заместителем начальника отдела Управления кадров ЦК ВКП(б) П. М. Кузнецовым и ответорганизатором В. И. Репиным, адресованная секретарям ЦК партии Г. М. Маленкову и А. С. Щербакову. Сотрудники аппарата ЦК партии доложили своим руководителям об итогах расследования: «В связи с тем, что вопросы, поднятые военным корреспондентом «Правды» т[оварищем] Шуром, обсуждены на Секретариате ЦК ВКП(б) в присутствии секретаря ЦК КП(б) Карело-Финской ССР т. Куприянова и по его докладу принято соответ- 
ствующее решение ЦК ВКП(б), считаем посылку ответорганизатора в Карело-Финскую ССР нецелесообразной» (РГАСПИ. Ф. 17. Оп. 121. А. 332. А. 91).

Аанная докладная записка многое проясняет. Вопрос действительно обсуждался в ЦК партии, но не на заседании Секретариата ЦК, которые в то время вел Г. М. Маленков, а на рабочем совещании в аппарате Секретариата ЦК ВКП(б), о чем работники Управления кадров доложили секретарям ЦК Маленкову и Щербакову. Обсуждение «карельского вопроса» не было оформлено протоколом заседания Секретариата ЦК. На этом аппаратном совещании не присутствовал инициатор «карельского вопроса» военкор «Правды» М. М. Шур (в это время он находился на 3-м Белорусском фронте, осуществлявшем наступательную операцию), не было и представителей газеты «Правда».

Такова недолгая история «карельского вопроса». Поручение Маленкова сотрудниками его аппарата было выполнено в короткие сроки. Показательно, что в ведомстве А. А. Жданова вопрос был снят с контроля и оказался в текущем архиве уже 29 августа 1944 г. (!), в секретариате Маленкова - 8 сентября.

Возникает вопрос: о каком же «соответствующем решении ЦК ВКП(б)» упоминали сотрудники аппарата ЦК? Протокол Секретариата ЦК ВКП(б) от 31 августа 1944 г. содержит постановление ЦК «О недостатках политической работы среди населения районов Карело-Финской ССР, освобожденных от финской оккупации», которое публиковалось во многих документальных изданиях. Объем документа - одна страница текста. Содержание постановления охватывает лишь один из аспектов национального вопроса. Следует обратить внимание на главный тезис указанного краткого постановления: «ЦК ВКП(б) отмечает, что массово-политическая работа поставлена неудовлетворительно» (РГАСПИ. Ф. 17. Оп. 116. А. 169. А. 21). Обычный дежурный вопрос: подобные решения принимались по всем областям страны, освобожденным от оккупации. Указанный документ имеет порядковый номер - п. 115гс. Аббревиатура «гс» означает - «принято голосованием», т. е. опросом. В годы войны в руководящих партийных органах, включая Политбюро, Секретариат и Оргбюро ЦК ВКП(б), голосование опросом по оперативным делам между заседаниями было обычной практикой.

Решение «карельского вопроса» являлось прерогативой «высшей инстанции»Верховного главнокомандующего И. В. Сталина. Аанное утверждение объясняется геополитической ситуацией, сложившейся на Севере. «Карельский вопрос»никак не вписывался в сценарий сталинской стратегии и политики.

Высшее руководство СССР летом 1944 г. определило в качестве главной задачи политический курс на изоляцию Финляндии от гитлеровской Германии и выведение ее из состояния войны с СССР. 19 сентября 1944 г. в Москве было заключено перемирие. В воспоминаниях бывшего резидента внешней разведки в Финляндии генерала Е. Т. Синицына раскрывается конкретная цена и значение этого события. Руководитель советской резидентуры, работавший под прикрытием (помощником политического советника руководителя Союзной контрольной комиссии (СКК) в Финляндии А. А. Жданова), практически ежедневно докладывал Жданову текущую агентурную информацию. Непосредственно от председателя СКК он получал данные об оценке ситуации, был свидетелем его телефонных консультаций со Сталиным по линии секретной связи. Сам генерал-полковник Жданов был склонен к варианту принуждения Финляндии к безоговорочной капитуляции. Однако заключение перемирия дало возможность перебросить значительные резервы (600 тыс. солдат и офицеров) на фронт 
с Германией. Вариант с безоговорочной капитуляцией Финляндии обошелся бы в миллион солдат (включая оккупационную администрацию, гарнизоны и пр.). Кроме того, требовалось ускорить наступление против Гитлера, чтобы не дать заключить сепаратный мир с западными союзниками (о подобных планах у руководства страны имелась достоверная информация) (см.: Синицын, 1996: 215). Помимо указанных аргументов, по условиям перемирия с СССР от 19 сентября Финляндия обязалась освободить свою территорию от немецких войск, что было осуществлено в ходе так называемой Мапландской войны.

Учитывая изложенные события, трудно представить даже гипотетическую вероятность неких насильственных мероприятий в отношении финно-угорского населения в освобожденных районах. Идея депортация могла привести к обострению военнополитической ситуации и срыву переговоров с Финляндией, что противоречило стратегической позиции руководства СССР.

\section{ПОЗИЦИЯ КОМАНАОВАНИЯ КАРЕАЬСКОГО ФРОНТА}

В архивных фондах не удалось обнаружить каких-либо письменных свидетельств, хотя бы косвенных, о реальных проектах военного командования Карельского фронта добиться осуществления депортации финно-угорского населения Карелии. В личном фонде И. В. Сталина (внутренняя опись писем и заявлений в его адрес за период 19 января - 25 декабря 1944 г. РГАСПИ. Ф. 558. Оп. 11. А. 886) также нет никаких материалов по данной проблеме.

Сохранились дишь воспоминания свидетелей, утверждавших, что отдельные члены Военного совета Карельского фронта действительно высказывали и обсуждали возможность проведения подобной операции по аналогии с депортациями ряда народов на юге страны. Наиболее активным в этом отношении был член Военного совета фронта генерал-лейтенант Т. Ф. Штыков, сохранивший также должность второго секретаря Аенинградского обкома партии. Опыт массовых выселений у ленинградских руководителей, включая Штыкова, имелся (можно назвать репрессии и принудительное выселение ингерманландцев из Аенинградской области в 1930-е гг. и в военные годы). Взрослые и дети были поставлены на грань физического выживания (см.: Васильев, 1992: 79-85). В марте 1942 г. из блокадного Иенинграда по Аороге жизни большую группу ингерманландцев отправили на необитаемые острова Северного Аедовитого океана (см.: Васильев, 2018: 208-211).

Возможно, учитывая конъюнктуру 1944 г. (массовые депортации ряда народов на юге страны), отдельные представители командования Карельского фронта, ранее имевшие успешный опыт наступательных операций на Волховском фронте, вынашивали идею депортации, пытаясь добыть веские свидетельства о якобы массовом сотрудничестве представителей финно-угорского населения с финскими оккупационными властями. Подобное обвинение воспринималось в качестве критики в адрес партийного руководства Карело-Финской республики и лично первого секретаря Г. Н. Куприянова.

Многие члены обновленного весной 1944 г. состава Военного совета Карельского фронта имели немалый довоенный опыт руководящей работы в партийных аппаратах, что не могло не наложить отпечаток на их поведение и стиль руководства в штабе фронта. Начальник Политуправления фронта генерал К. Ф. Калашников до войны работал секретарем Московского горкома партии, генерал-майор К. С. Грушевой был секретарем Анепропетровского обкома КП(б) Украины. Генерал Т. Ф. Штыков сохра- 
нял должность второго секретаря Аенинградского обкома ВКП(б), являлся кандидатом в члены ЦК ВКП(б). Он был заинтересован в восполнении территориальных потерь Аенинграда после выделения из Ценинградской области нескольких районов и передачи их в состав Новгородской и Псковской областей. Частично этот вопрос был решен: из Карело-Финской республики передали в состав Аенинградской области территории Выборгского, Кексгольмского и Яскинского районов, города Выборг и Кексгольм.

Проведенное документальное расследование показало, что представители командования Карельского фронта не могли участвовать в обсуждении национального вопроса в Москве в последние дни августа 1944 г., поскольку занимались исполнением срочных военных приказов Ставки Верховного главнокомандования по организации наступательных операций сначала на территории Карелии, затем в Заполярье (см.: Васильев, 2018: 211-218). Как свидетельствуют журналы записи лиц, принятых Сталиным в его кабинете в Кремле, в хронологический период наступления Карельского фронта против финляндских войск (июнь - август 1944 г.) генерал-лейтенант Штыков однажды зафиксирован в числе посетителей кабинета Сталина. Он сопровождал командующего фронтом К. А. Мерецкова, вызванного на совещание 25 августа 1944 г., в котором участвовали Г. М. Маленков, В. М. Молотов, А. П. Берия, А. С. Щербаков, а также первый заместитель начальника Генштаба генерал армии А. И. Антонов и начальник Оперативного управления Генштаба С. М. Штеменко. Совещание проходило ровно 1,5 часа (22.20-23.50)1. Политическое руководство страны поставило оперативные задачи Генштабу и Карельскому фронту в отношении дальнейших действий с учетом изменившейся политической ситуации в августе 1944 г., после чего руководители фронта сразу же отправились их выполнять. Поэтому физически генерал Штыков уже не мог быть в Москве в последних числах августа, когда в ЦК ВКП(б) рассматривался национальный вопрос. Перед командованием Карельского фронта стояла новая важная задача - в ближайшее время начать наступление против немецких войск в Заполярье. Отвлекаться на обсуждение других вопросов, не связанных с действиями фронта, никто бы не позволил. Принципиальные политические вопросы решал сам И. В. Сталин (см.: Васильев, Шепелев, 2016).

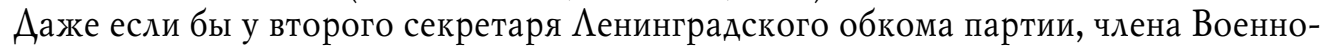
го совета Карельского фронта генерал-лейтенанта Т. Ф. Штыкова появились намерения организации выселения местного финно-угорского населения, то он должен был заручиться поддержкой члена ГКО, своего непосредственного руководителя в партии - секретаря ЦК и первого секретаря Аенинградского обкома партии А. А. Жданова. Однако в указанные временные рамки не зафиксировано посещений Штыковым ни Смольного, ни кабинета Жданова в Москве2 ${ }^{2}$ Штыкову действительно в 1943 и 1944 гг. доводилось быть в кабинете Сталина в Кремле, однако практически во всех случаях он сопровождал своих непосредственных руководителей на совещаниях

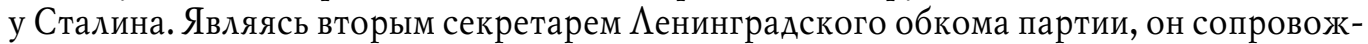
дал первого секретаря, члена Политбюро ЦК ВКП(б) А. А. Жданова. В качестве члена Военного совета Волховского фронта (с апреля 1943 г.), Карельского фронта (с февраля 1944 г.), позднее 1-го Аальневосточного (в 1945 г.) Штыков сопровождал командующего фронтом К. А. Мерецкова. Как свидетельствуют данные Архива Президента РФ, вместе со Ждановым на совещаниях у Сталина Штыков находился в 1944 г. 1 марта, 5 мая, 11 июня - со Ждановым и Мерецковым, 18 февраля, 25 августа, 2 ноября - с Мерецковым³. 
Примечательно, что в послевоенных мемуарах бывшего командующего Карельским фронтом маршала К. А. Мерецкова нет ни слова о «карельском вопросе» (см.: Мерецков, 1988). В воспоминаниях бывшего начальника Политуправления фронта генерал-лейтенанта К. Ф. Калашникова также нет никаких упоминаний по этому поводу. Более того, Калашников привел примеры помощи наступающим войскам со стороны местного населения (см.: Калашников, 1981: 172-174).

\section{ЗАКАЮЧЕНИЕ}

Аепортация в 1944 г. финно-угорского населения в Аенинградской области и Карело-Финской ССР была предотвращена благодаря указанию «высшей инстанции» Верховного главнокомандующего И. В. Сталина. Решающим фактором для подобного политического решения послужила сложившаяся на Севере геополитическая ситуация, связанная с необходимостью добиться изоляции Финляндии от гитлеровской Германии и выведения ее из состояния войны с СССР. В результате перемирия, заключенного в Москве 19 сентября 1944 г., были получены огромные резервы и средства для их передислокации на борьбу с Германией (до миллиона солдат и офицеров). Насильственные мероприятия в отношении местного населения, этнически родственного финнам, не вписывались в сценарий сталинской стратегии и политики, поскольку могли привести к срыву мирного договора.

Военный корреспондент газеты «Правда» М. М. Шур оказался автором постановки «карельского вопроса», определяемого как угроза насильственного выселения карел, финнов, вепсов, ингерманландцев и других народов из родных мест проживания в отдаленные регионы страны. Основанием для депортации могли служить заявления отдельных руководителей командования Карельского фронта о якобы пособничестве местного населения в период финляндской и немецкой оккупации северо-западных территорий СССР. Военкор-правдист Шур в докладной записке в редколлегию главного партийного издания страны в категорической форме отверг подобные утверждения и обосновал их абсурдность.

Значимость национального вопроса получила выражение в рассмотрении и обсуждении его в аппарате ЦК ВКП(б) с непосредственным участием высшего партийного руководства - секретарей ЦК партии Г. М. Маленкова, А. А. Жданова, А. С. Щербакова. Аокументы Российского государственного архива социально-политической истории свидетельствуют о том, что «карельский вопрос» решался на высшем уровне. Партийные руководители Карело-Финской ССР Г. Н. Куприянов и Аенинградского обкома партии Т. Ф. Штыков являлись исполнителями указаний и приказов сверху. Поэтому их роль в решении национального вопроса (в том числе, в качестве членов Военного совета Карельского фронта) нельзя преувеличивать.

\section{ПРИМЕЧАНИЯ}

${ }^{1}$ См.: Исторический архив. 1998. № 4. С. 196; 1996. № 4. С. 84-85.

${ }^{2}$ См.: Журнал посещений А. А. Жданова, 1941-1944 гг. СПб., 2014. С. 380.

3 См.: Исторический архив. 1998. № 4. С. 196.

\section{СПИСОК АИТЕРАТУРЫ}

Васильев, Ю. А. (1992) Аеревня на распутье. К возрождению села: формирование условий жизнедеятельности и культуры быта. М. : Молодая гвардия. 146 с.

Васильев, Ю. А. (2018) Юрий Андропов. На пути к власти. М. : Вече. 416 с. 
Васильев, Ю. А., Шепелев, В. Н. (2016) Борьба политических элит в условиях позднего сталинизма. Карельский отголосок «Иенинградского дела». 1949-1950 гг. // Исторический архив. № 3. C. 3-31.

Веригин, С. Г. (2009) Карелия в годы военных испытаний: политическое и социально-экономическое положение Советской Карелии в период Второй мировой войны 1939-1945 гг. Петрозаводск : Изд-во ПетрГУ. 544 с.

Калашников, К. Ф. (1981) Право вести за собой. М. : Воениздат. 239 с.

Мерецков, К. А. (1988) На службе народу. 5-е изд. М. : Политиздат. 447 с.

Синицын, Е. Т. (1996) Резидент свидетельствует. М. : Гея. 288 с.

Уйтто, А. (2017) «Финноед» Отто Вилле Куусинен. СПб. : Гйоль. 388 с.

Аата поступления: 15.03.2020 г.

\section{HOW THE DEPORTATION OF THE FINNO-UGRIC PEOPLES \\ IN 1944 WAS PREVENTED \\ YU. A. VASILYEV \\ MOSCOW UNIVERSITY FOR THE HUMANITIES}

The article highlights the unique and almost unknown historical fact of preventing the deportation of the Finno-Ugric population of the USSR in 1944 in the Leningrad Region and the Karelian-Finnish SSR, liberated from occupation by the Karelian Front. It was first mentioned in the Finnish media in the late 1980s and early 1990s. However, there is still no scientific historiography on this issue.

According to documents of the Russian State Archive of Socio-Political History (RGASPI), discovered as a result of the researcher's inquiry, during the offensive of the Karelian Front in June August 1944, there was a real threat of a possible eviction of Ingermanlanders, Karelians, Finns, Vepsians and other indigenous northern peoples who found themselves in the territory occupied by Finnish and German troops during the years of the Great Patriotic War.

The author reveals the content of the memorandum written by the war correspondent for the newspaper "Pravda" M. M. Shur to the editorial board of the USSR main party organ, in which the presence of a threat of violent measures against the Finno-Ugric population was indicated in stark terms. According to the war correspondent's definition, the aggravation of the national issue was called the "Karelian issue". The author covers collisions related to its further discussion in the Central Committee of the All-Union Communist Party of the Bolsheviks and to the participation of the highest party leaders: the secretaries of the Central Committee of the party G. M. Malenkov, A. A. Zhdanov, A. S. Shcherbakov, chief editor of the newspaper "Pravda" P. N. Pospelov.

According to the author, the prevention of deportation in the North in 1944 was carried out at the direction of the "highest authority" - Supreme Commander I. V. Stalin. The adoption of this decision was justified by the geopolitical situation, the state interests of the USSR and Finland, which resulted in the conclusion of a ceasefire in Moscow on September 19, 1944.

Keywords: Great Patriotic War; Karelian Front; Karelian issue; deportation; Secretariat of the Central Committee of the All-Union Communist Party of the Bolsheviks; I. V. Stalin; M. M. Shur; G. N. Kupriyanov; T. F. Shtykov

\section{REFERENCES}

Kalashnikov, K. F. (1981) Pravo vesti za soboi. Moscow, Voenizdat. 239 p. (In Russ.).

Meretskov, K. A. (1988) Na sluzbbe narodu. 5nd ed. Moscow, Politizdat. 447 p. (In Russ.).

Sinitsyn, E. T. (1996) Rezident svidetel'stvuet. Moscow, Geia. 288 p. (In Russ.).

Uitto, Antero. (2017) «Finnoed» Otto Ville Kuusinen. St. Petersburg, Giol'. 388 p. (In Russ.).

Vasiliev, Yu. A. (1992) Derevnia na rasput' e. K vozrozbdeniiu sela: formirovanie uslovii zbiznedeiatel' nosti i kul' tury byta. Moscow, Molodaia gvardiia. 146 p. (In Russ.).

Vasiliev, Yu. A. (2018) Iurii Andropov. Na puti k vlasti. Moscow, Veche. 416 p. (In Russ.). 
Vasiliev, Yu. A. and Shepelev, V. N. (2016) Bor'ba politicheskikh elit v usloviiakh pozdnego stalinizma. Karel'skii otgolosok «Leningradskogo dela». 1949-1950 gg. Istoricheskii arkbiv, no. 3. pp. 3-31. (In Russ.).

Verigin, S. G. (2009) Kareliia v gody voennykb ispytanii: Politicheskoe $i$ sotsial'no-ekonomicheskoe polozhenie Sovetskoi Karelii v period Vtoroi mirovoi voiny 1939-1945 gg. Petrozavodsk, Izd-vo PetrGU. 544 p. (In Russ.).

Submission date: 15.03 .2020$.

Васильев Юрий Альбертович - доктор исторических наук, профессор, профессор кафедры истории и регионоведения Московского гуманитарного университета. Адрес: 111395 , Россия, г. Москва, ул. Юности, д. 5. Тел.: +7 (499) 374-70-88. Эл. адрес: vasyural@mail.ru

Vasilyev Yuriy Albertovich, Doctor of History, Professor, Professor, Department of History and Regional Studies, Moscow University for the Humanities. Postal address: 5, Yunosti St., Moscow, Russian Federation, 111395. Tel.: +7 (499)374-70-88. E-mail: vasyural@mail.ru

DOI: $10.17805 /$ zpu.2020.2.3

\title{
Восток встречается с Западом: встреча советских и американских войск на реке Эльба в воспоминаниях участников
}

\author{
А. Б. Ручкин \\ ЦЕНТР ОБРАЗОВАНИЯ И КУЛЬТУРЫ «ГРИНТ», Г. МОСКВА
}

Формирование государственной политики по увековечиванию памяти о Великой Отечественной войне требует особого внимания к событиям, выходящим за рамки национального значения и затрагивающим историю и судьбы других народов. Встреча советских и американских войск, произошедшая 25 апреля 1945 г. на реке Эльба в самом центре Германии, рассматривается как важная веха и одновременно символ военно-политического взаимодействия СССР с союзниками по антигитлеровской коалиции, сохраняющие сегодня свою значимость и актуальность как пример успешного сотрудничества объединенных наций по противостоянию глобальным угрозам и вызовам.

На основе воспоминаний солдат и офицеров союзных армий, мемуаров высшего командования советских и американских войск, рассекреченных документальных материалов из архива Министерства обороны РФ и медийных проектов радиостанции «Радио Свобода» в статье реконструируется «образ союзника», сложившийся в ходе индивидуальных и коллективных контактов во время встреч в зоне соприкосновения союзных армий, рассматриваются попытки его коррекции в ходе идеологического противостояния периода холодной войны.

Политическая значимость самого события и сохранения «духа Эльбы» как важной смысловой конструкции межгосударственных отношений прослеживается на примере выступлений и совместных заявлений руководителей СССР, России и США, анализируется их восприятие в зарубежном общественно-политическом пространстве. Автор формулирует исторические уроки и общие концептуальные подходы по актуализации и использованию потенциала встречи на Эльбе для развития российско-американских отношений в современных условиях.

Ключевые слова: США; встреча на Эльбе; образ союзника; холодная война; российскоамериканские отношения; Великая Отечественная война; Вторая мировая война; историческая память 